\title{
Field controlled experiments of mercury accumulation in crops from air and soil
}

\author{
Zhenchuan Niu, Xiaoshan Zhang, Zhangwei Wang*, Zhijia Ci \\ Research Center for Eco-Environmental Sciences, Chinese Academy of Sciences, P.O. Box 2871, Beijing 100085, China
}

\section{A R R T I C L E I N F O}

\section{Article history:}

Received 3 April 2011

Received in revised form

27 May 2011

Accepted 28 May 2011

\section{Keywords:}

Mercury

Crop

Correlation

Open top chambers

Plant accumulation

\begin{abstract}
A B S T R A C T
Field open top chambers (OTCs) and soil mercury (Hg) enriched experiments were employed to study the influence of $\mathrm{Hg}$ concentrations in air and soil on the $\mathrm{Hg}$ accumulation in the organs of maize (Zea mays L.) and wheat (Triticum aestivum L.). Results showed that $\mathrm{Hg}$ concentrations in foliages were correlated significantly $(p<0.05)$ with air $\mathrm{Hg}$ concentrations but insignificantly correlated with soil Hg concentrations, indicating that $\mathrm{Hg}$ in crop foliages was mainly from air. $\mathrm{Hg}$ concentrations in roots were generally correlated with soil $\mathrm{Hg}$ concentrations $(p<0.05)$ but insignificantly correlated with air $\mathrm{Hg}$ concentrations, indicating that $\mathrm{Hg}$ in crop roots was mainly from soil. No significant correlations were found between $\mathrm{Hg}$ concentrations in stems and those in air and soil. However, $\mathrm{Hg}$ concentrations in upper stems were usually higher than those in bottom stems, implying air $\mathrm{Hg}$ might have stronger influence than soil $\mathrm{Hg}$ on stem $\mathrm{Hg}$ accumulation.
\end{abstract}

(c) 2011 Elsevier Ltd. All rights reserved.

\section{Introduction}

Mercury $(\mathrm{Hg})$ is a persistent and toxic heavy metal, and 95\% of the atmospheric $\mathrm{Hg}$ is in the term of gaseous elemental mercury (GEM) (Fitzgerald et al., 1991). Because of its long atmospheric lifetime (about one year), GEM may spread all over the world through the long-range atmospheric transport (Lindqvist and Rodhe, 1985). Current studies have identified that the strength of known sources of atmospheric $\mathrm{Hg}$ is greater than previously realized (Gustin et al., 2000; Engle et al., 2001; Pirroni et al., 2001), and the role of vegetation in $\mathrm{Hg}$ biogeochemical cycle has attracted more and more attentions (Veiga et al., 1994; Lindberg, 1996; Lindberg et al., 2004; St. Louis et al., 2001; Obrist, 2007; Friedli et al., 2009), e.g., vegetation as the missing sink in global $\mathrm{Hg}$ mass balance (Gustin et al., 2008). A critical question eager for answer in the global $\mathrm{Hg}$ cycling is whether the large amount of $\mathrm{Hg}$ stored in vegetation originates from the soil or from the atmosphere (Ericksen et al., 2003).

Previous studies have shown that the $\mathrm{Hg}$ in tree foliages was mainly originated from air, while the $\mathrm{Hg}$ in tree roots was mainly from soil (Barghigiani et al., 1991; Frescholtz et al., 2003; Ericksen et al., 2003; Millhollen et al., 2006a). Roots act as a critical barrier for the transport of soil $\mathrm{Hg}$ to the aboveground of trees (Bishop et al., 1998; Rea et al., 2002; Ericksen et al., 2003; Fay and Gustin, 2007).

\footnotetext{
* Corresponding author.

E-mail addresses: zhangxsh@rcees.ac.cn (X. Zhang), wangzhw@rcees.ac.cn (Z. Wang).
}

However, there are still some controversies on the accumulation of $\mathrm{Hg}$ in herbaceous plant organs. Greger et al. (2005) reported that only a small part $(0.17-2.5 \%)$ of soil $\mathrm{Hg}$ was translocated to the shoots for five crop species, whereas Schwesig and Krebs (2003) reported that the percentages of $\mathrm{Hg}$ from soil in the foliages of Deschampsia flexuosa L and Calamagrostis villosa (Chaix ex Vill.) were $30 \%$ and $93 \%$, respectively.

Crop is an important component of land vegetation. The area of arable land is $1.4 \times 10^{9}$ ha (FAO, 2009), accounting for $9.5 \%$ of global land area. Moreover, crop is closely linked to human and livestock health through daily consumption. So, it is doubtless that the investigation on the role of crop in the biogeochemical cycle of $\mathrm{Hg}$ is important. In this paper field open top chambers (OTCs) and soil Hg enriched experiments were conducted to study the correlations of $\mathrm{Hg}$ concentrations in crop organs with those in air and soil.

\section{Materials and methods}

\subsection{Site description}

The field experimental site is located at a small village $\left(\mathrm{N} 38.70^{\circ}, \mathrm{E} 115.23^{\circ}\right)$ in Wangdu County, Hebei Province, which is in the center of Huabei Plain. This plain is one of the major crop producing areas in China, mainly planted by maize and wheat in rotation. This site has a typical warm and continental monsoon climate. The average annual temperature and rainfall are $12.3^{\circ} \mathrm{C}$ and $555.0 \mathrm{~mm}$, respectively. The highest and lowest monthly mean air temperatures are $26.5^{\circ} \mathrm{C}$ in July and $-4.1^{\circ} \mathrm{C}$ in January. The temperature of top soil $(10 \mathrm{~cm})$ varies from $-4{ }^{\circ} \mathrm{C}$ in January to $35^{\circ} \mathrm{C}$ in July. This site is far away from cities and factories. The $\mathrm{Hg}$ concentrations in soil and air at this site were $25 \pm 6 \mathrm{ng} \mathrm{g}^{-1}$ and $2 \pm 1 \mathrm{ng} \mathrm{m}^{-3}$, respectively. The basic properties of field soil were analyzed based on the methods described by Bao (2000). The soil $\mathrm{pH}$ was $7.4 \pm 0.2$, alkali-hydrolyzable nitrogen $62.0 \pm 15.0 \mu \mathrm{g} \mathrm{g}^{-1}$, available phosphorus $12.0 \pm 4.0 \mu \mathrm{g} \mathrm{g}^{-1}$, and available potassium $98.0 \pm 4.0 \mu \mathrm{g} \mathrm{g}^{-1}$. 


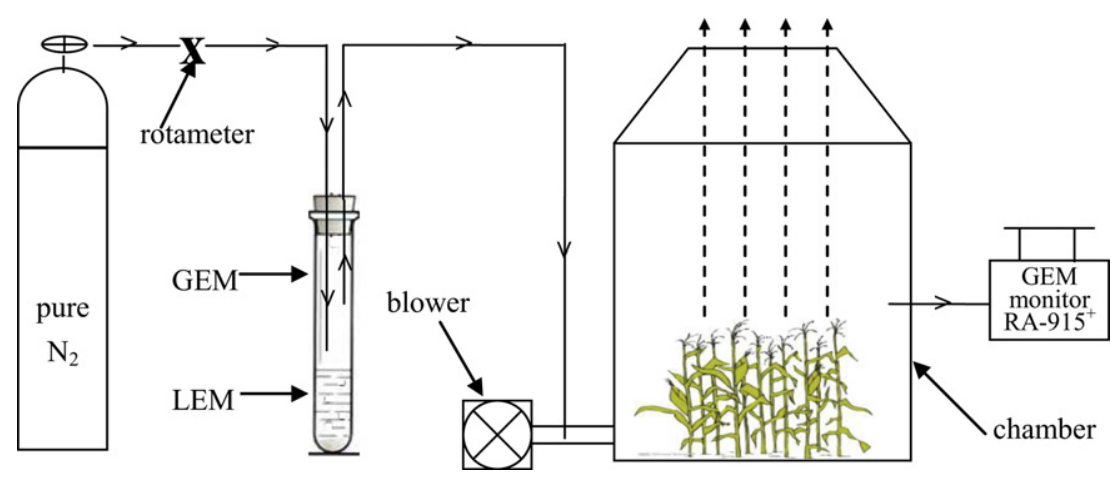

Fig. 1. The structure and equipments of the open top chambers. (gaseous elemental mercury (GEM), liquid elemental mercury (LEM)).

\subsection{Experimental crop and management}

Summer maize (Zea mays L., cv. Xianyu 335) and winter wheat (Triticum aestivum L., cv. Shixin 733) were selected as the typical representatives of crops in the both field experiments, i.e. open top chambers (OTCs) and soil Hg enriched experiments. The OTCs experiment was conducted during maize growing season (July to October) and wheat growing season (October to June next year). The soil Hg enriched experiment was conducted simultaneously. The management for the two crops followed local agronomic manners.

\subsection{Open top chambers (OTCS) experiment}

Field OTCs experiment was employed to study the correlations of Hg concentrations between air and crop organs. Field OTCs can provide more closely ambient conditions than closed-top chambers. The temperature and relative humidity within OTCs were similar to ambient conditions (Heagle et al., 1973). In this study, the OTCs were Heagle-type with the upper part a $23.6^{\circ}$ tilted frustum (Fig. 1). The height of the chambers was $2.0 \mathrm{~m}$, bottom diameter $1.5 \mathrm{~m}$ and top diameter $1.0 \mathrm{~m}$. The volume of the chambers was about $3.3 \mathrm{~m}^{3}$. The frames of OTCs were made of steel bars with the frustum and side sections covered by $3.0 \mathrm{~mm}$ thick polyvinyl chloride plastic film.

The GEM was generated from the evaporation of a small amount of liquid elemental $\mathrm{Hg}$ in a glass tube (length of $60.0 \mathrm{~cm}$, diameter of $1.5 \mathrm{~cm}$ ). The tube was buried into deep soil $(60.0 \mathrm{~cm})$ where diurnal variation of temperature was less than $0.5^{\circ} \mathrm{C}$. The temperature was measured by a ZDR-21J temperature recorder (Zeda Co., Ltd, China).

The GEM in the glass tube was carried out by the pure $\mathrm{N}_{2}$ flow through a Teflon tube (inner diameter of $2.0 \mathrm{~mm}$ ) into the air flow $\left(2.5 \mathrm{~m}^{3} \mathrm{~min}^{-1}\right)$ in pipe (PVC, inner diameter of $7.5 \mathrm{~cm}$ ) from a centrifugal blower to a chamber for obtaining a GEM mixed air to fill into the chamber from bottom. The PVC pipe in the chamber was perforated equidistantly for GEM mixed air to disperse easily. The GEM mixed air in the chamber was vented from the top of the chamber, and the time for a complete exchange of the air in the chamber was estimated to be about $80 \mathrm{~s}$.

The GEM concentrations of the mixed air into the chambers can be set to certain of values by the carrier gas $\left(\mathrm{N}_{2}\right)$ flow rate controlled by an adjustable rotameter During the experiments the GEM concentrations were monitored for $10 \mathrm{~min}$ in the morning, midday and afternoon every day by a RA- $915^{+}$Zeeman atomic absorption spectrometry Hg analyzer (Lumex Inc., Russia). When a variation of GEM concentration in a chamber was over $10 \%$ of the set value, the carrier gas rate was adjusted by rotameter to obtain the desired GEM concentrations.

Four levels of $\mathrm{Hg}$ concentrations in mixed air, $2 \pm 1,10 \pm 1,20 \pm 2$ and $50 \pm 2 \mathrm{ng} \mathrm{m}^{-3}$ were set for OTCs experiment of maize. The level of $\mathrm{Hg}$ concentration of $2 \pm 1 \mathrm{ng} \mathrm{m}^{-3}$ was set for control check (CK). For OTCs experiment of wheat, the highest concentration of mixed air $\mathrm{Hg}$ was set to $70 \pm 2 \mathrm{ng} \mathrm{m}^{-3}$. Three replicative chambers were set for each concentration level. Total 12 chambers were set for this experiment. The distance between chambers was at least $3.0 \mathrm{~m}$ to avoid the mutual shading. The OTCs exposure experiment for maize was from July to October, and then for wheat was from October to next year June.

\subsection{Soil Hg enriched experiment}

Soil $\mathrm{Hg}$ enriched experiment was employed to study the correlations between $\mathrm{Hg}$ concentrations in soil and those in crop organs. Mercuric chloride $\left(\mathrm{HgCl}_{2}\right)$ is commonly used in the soil $\mathrm{Hg}$ enriched experiment (Millhollen et al., 2006a, 2006b; Dunagan et al., 2007; Stamenkovic and Gustin, 2009). Five soil Hg concentrations were set in the soil $\mathrm{Hg}$ enriched experiment, including a CK soil treated by the solution without $\mathrm{HgCl}_{2}$. The field area for each plot was $4 \mathrm{~m}^{2}$, and the depth of field soils treated by $\mathrm{HgCl}_{2}$ solutions was $30 \mathrm{~cm}$. To obtain the soil $\mathrm{Hg}$ concentration gradients, five $\mathrm{HgCl}_{2}$ solutions with the volume of $30 \mathrm{~L}$ and the concentration of 0 ,
$10,20,30$ and $50 \mathrm{mg} \mathrm{L}^{-1}$ were added to the five field soils, respectively, and then the soils were homogenized respectively by thoroughly mixing.

Before the maize was seeded down, the $\mathrm{HgCl}_{2}$ enriched soils were aged for about 6 months, and then covered by the non-enriched soil $(1-2 \mathrm{~cm})$ to establish a buffer layer to minimize the photoreduction and emission of $\mathrm{Hg}$. Zhu et al. (1996) indicated that the fractions of active $\mathrm{Hg}$, alkaline soluble $\mathrm{Hg}$ and acid soluble $\mathrm{Hg}$ were gradually transformed to residual $\mathrm{Hg}$ over time after the soil was enriched by $\mathrm{HgCl}_{2}$ solution, and residual $\mathrm{Hg}$ was dominated the speciation (50-75\%) after 6 months. Ericksen et al. (2005) reported that there was an immediate $\mathrm{Hg}$ release after the soil was enriched by $\mathrm{HgCl}_{2}$, and then the emission decreased exponentially, finally followed by a relatively steady flux after 62 days. Therefore, in this study, the field soils were aged for 6 months.

When the maize was seeded down, the soil $\mathrm{Hg}$ concentrations were measured to be as $25 \pm 6(\mathrm{CK}), 158 \pm 45,325 \pm 59,496 \pm 63$ and $763 \pm 133 \mathrm{ng} \mathrm{g}^{-1}$. For wheat case, the $\mathrm{Hg}$ concentrations were measured to be as $28 \pm 3$ (CK), $57 \pm 22,119 \pm 26$, $243 \pm 55$ and $552 \pm 28 \mathrm{ng} \mathrm{g}^{-1}$. The decease of $\mathrm{Hg}$ concentration is due to the $\mathrm{Hg}$ emission to air and the uptake of plant roots from soil.

\subsection{Sample collection and measurement}

Maize and wheat were sampled at later jointing (LJ) stage, grain filling (GF) stage and dough (D) stage. Crop organs including roots, stems, foliages and seeds were collected, and sheaths were removed from stems and foliages. The collection positions at each stage were consistent. Since the stems of the crops were very long and the quantity of samples to be analyzed was very little, the stems of maize and wheat were divided equally into upper and bottom stems. The foliages of maize were further divided into upper and bottom foliages like stems. For wheat, only upper foliages were collected because the bottom foliages were deciduous.

The samples of plant were collected in plastic self-sealing bags, and then were rinsed by both tap water and ultra pure deionized water in order. The field soils in the soil $\mathrm{Hg}$ enriched experiment and chamber soils were sampled both before and at the end of the experiment. Plant samples were dried at $55^{\circ} \mathrm{C}$, and soil samples were air-dried. All the samples were ground, homogenized, and then stored at $-4{ }^{\circ} \mathrm{C}$ for analysis.

The Hg concentrations in plant and soil samples were measured by RA- $915^{+} \mathrm{Hg}$ analyzer attached with PYRO-91 thermal decomposition accessory from Lumex Inc. Some researchers have used this instrument successfully for measuring $\mathrm{Hg}$ concentrations in plant and soil samples (Chen et al., 2001; Shuvaeva et al., 2008; Wang et al., 2009). The samples were directly thermally decomposed in atomizer chamber at $750{ }^{\circ} \mathrm{C}$ with the aided catalytic action to transform all the form $\mathrm{Hg}$ into

\section{Table 1}

Root $\mathrm{Hg}$ concentrations in maize and wheat at different growth stages in the OTCs experiment $\left(\mathrm{ng} \mathrm{g}^{-1}\right) .^{\mathrm{a}}$

\begin{tabular}{llrrrr}
\hline Species & Stages & $2\left(\mathrm{ng} \mathrm{m}^{-3}\right)$ & $10\left(\mathrm{ng} \mathrm{m}^{-3}\right)$ & $20\left(\mathrm{ng} \mathrm{m}^{-3}\right)$ & $50 / 70\left(\mathrm{ng} \mathrm{m}^{-3}\right)$ \\
\hline Maize & LJ & $3.3 \pm 2.4(\mathrm{a})$ & $6.0 \pm 1.9(\mathrm{a})$ & $6.1 \pm 1.4(\mathrm{a})$ & $6.2 \pm 0.3(\mathrm{a})$ \\
& GF & $9.1 \pm 2.9(\mathrm{a})$ & $8.7 \pm 2.5(\mathrm{a})$ & $6.8 \pm 1.2(\mathrm{a})$ & $10.1 \pm 3.4(\mathrm{a})$ \\
& D & $3.8 \pm 1.5(\mathrm{a})$ & $2.6 \pm 1.1(\mathrm{a})$ & $3.4 \pm 1.5(\mathrm{a})$ & $4.1 \pm 1.4(\mathrm{a})$ \\
& & & & & \\
Wheat & LJ & $10.9 \pm 1.2(\mathrm{a})$ & $8.4 \pm 2.1(\mathrm{a})$ & $11.8 \pm 4.5(\mathrm{a})$ & $12.7 \pm 2.6(\mathrm{a})$ \\
& GF & $9.3 \pm 1.9(\mathrm{a})$ & $8.6 \pm 2.7(\mathrm{a})$ & $10.0 \pm 1.4(\mathrm{a})$ & $11.5 \pm 1.7(\mathrm{a})$ \\
& D & $5.8 \pm 0.7$ (a) & $11.3 \pm 1.4(\mathrm{~b})$ & $10.4 \pm 2.2(\mathrm{ab})$ & $25.0 \pm 4.4(\mathrm{c})$ \\
\hline
\end{tabular}

a In the same row values marked with the same letters in brackets are not significantly different at the 0.05 levels. The air $\mathrm{Hg}$ concentration of $50 \mathrm{ng} \mathrm{m}^{-3}$ was for maize, and $70 \mathrm{ng} \mathrm{m}^{-3}$ for wheat. The growth stage: Later Jointing (LJ), Grain Filling (GF), and Dough (D). The same below. 


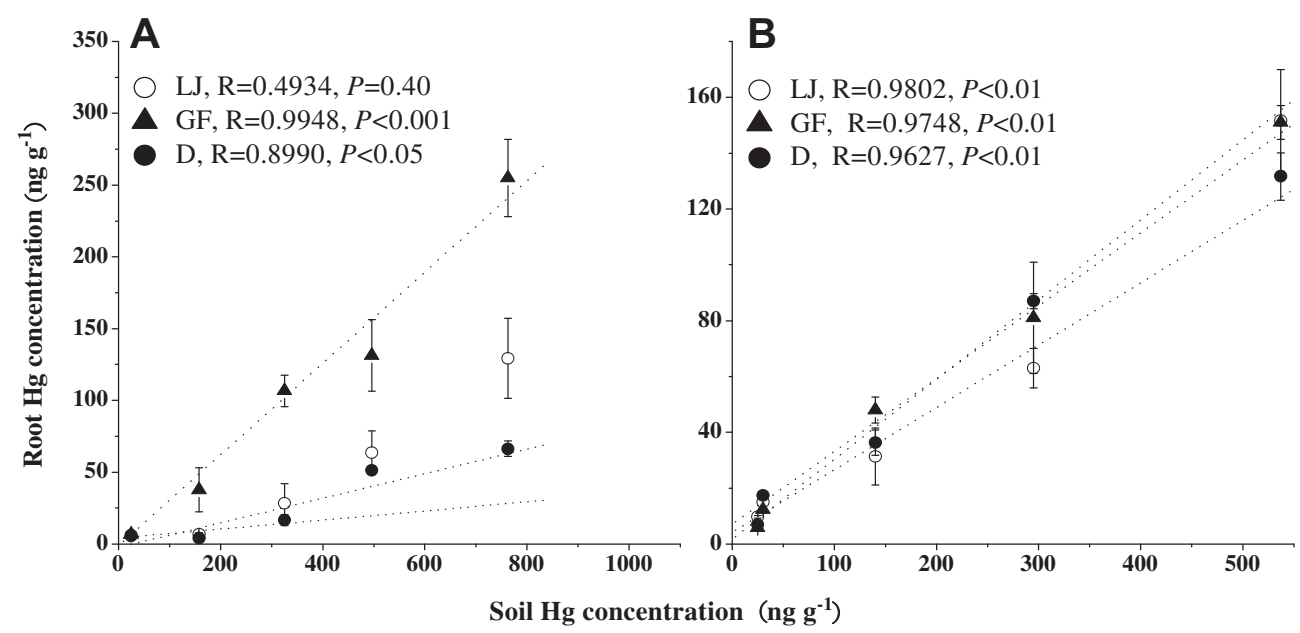

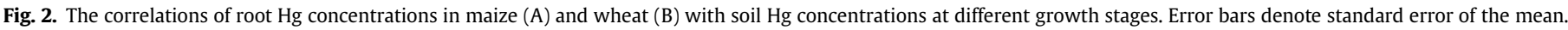
(The growth stage: Later Jointing (LJ), Grain Filling (GF), Dough (D), the same below).

$\mathrm{Hg}^{0}$, and then $\mathrm{Hg}^{0}$ was detected by the RA- $915^{+}$analyzer. Each sample was analyzed for three times to get an average value. The calibration curves were confirmed by soil standards (GBW07404, $590 \mathrm{ng} \mathrm{g}^{-1}$ ) and peach foliages standards (GBW08501, $40 \mathrm{ng} \mathrm{g}^{-1}$ ) respectively. The standard samples were also measured for calibration after every ten samples. The detection limit of the instrument was $5 \mathrm{pg}$ of $\mathrm{Hg}$ for measuring solid sample. The precisions, obtained from ten replicate determinations of standards, were $3.5 \%$ for soil, and $2.8 \%$ for peach foliages. The recoveries ranged from $94.2 \%$ to $104.9 \%$ for soil, and $92.5 \%-102.0 \%$ for peach foliages.

\subsection{Data analysis}

Correlations between the $\mathrm{Hg}$ concentrations in crop organs and those in air and soil were analyzed based on the data from OTCs and soil $\mathrm{Hg}$ enriched experiments. The variance analysis of $\mathrm{Hg}$ concentrations in the crop organs for the levels of $\mathrm{Hg}$ treatments in the two experiments was also performed. Data were presented as mean and standard deviation, and statistical significance was considered at $p<0.05$.

\section{Results}

\subsection{The correlation of $\mathrm{Hg}$ concentration between crop root and soil}

The root $\mathrm{Hg}$ concentrations in maize and wheat did not show significant correlations with the air $\mathrm{Hg}$ concentrations at all stages $(p>0.05)$ in OTCs experiment. Furthermore, the root Hg concentrations in maize did not show significant differences among various air $\mathrm{Hg}$ level treatments at all stages $(p>0.05)$, and also no such differences were shown for wheat at LJ and GF stages $(p>0.05)$. However, a pronounced higher $\mathrm{Hg}$ concentration in wheat root at the treatment of $70 \mathrm{ng} \mathrm{m} \mathrm{m}^{-3}$ was observed at D stage $(p<0.05)$ (Table 1).

Fig. 2 shows that significant positive correlations were commonly found between the $\mathrm{Hg}$ concentrations in both maize and wheat roots and the $\mathrm{Hg}$ concentrations in soil at all growth stages $(R=0.8990-0.9948, p<0.05)$, and an insignificant positive correlation was observed for maize at LJ stage $(R=0.4934, p>0.05)$. Therefore, the results from the two experiments indicated that the $\mathrm{Hg}$ accumulated in crop roots was mainly from soil, and air $\mathrm{Hg}$ may be able to affect the $\mathrm{Hg}$ accumulation in wheat roots at $\mathrm{D}$ stage when air $\mathrm{Hg}$ concentration reaches certain level ( $70 \mathrm{ng} \mathrm{m}^{-3}$ or higher).

\subsection{The influence of air and soil $\mathrm{Hg}$ on stem $\mathrm{Hg}$ accumulation}

For wheat and maize, the $\mathrm{Hg}$ concentrations in upper stems were not obviously correlated with both air and soil Hg concentrations at all stages $(p>0.05)$, and the same results were observed for bottom stems.

In OTCs experiment, the $\mathrm{Hg}$ concentrations in maize upper stems were not significantly different among the various air $\mathrm{Hg}$ level treatments at all the stages $(p>0.05)$, and the same results were observed for maize bottom stems $(p>0.05)$ (Table 2). For wheat, no obvious differences of $\mathrm{Hg}$ concentrations in bottom stems were observed at all growth stages $(p>0.05)$, but remarkably higher $\mathrm{Hg}$ concentrations in upper stems were observed at

Table 2

Stem $\mathrm{Hg}$ concentrations in maize and wheat at different growth stages in the OTCs and soil $\mathrm{Hg}$ enriched experiments (ng $\left.\mathrm{g}^{-1}\right)^{\mathrm{a}}$

\begin{tabular}{|c|c|c|c|c|c|c|c|c|c|c|c|}
\hline \multirow[t]{2}{*}{ Species } & \multirow[t]{2}{*}{ Stages } & \multirow[t]{2}{*}{ Stems } & \multicolumn{4}{|c|}{ Air Hg concentrations $\left(\mathrm{ng} \mathrm{m}^{-3}\right)$} & \multicolumn{5}{|c|}{ Soil $\mathrm{Hg}$ concentrations $\left(\mathrm{ng} \mathrm{g}^{-1}\right)$} \\
\hline & & & 2 & 10 & 20 & $50 / 70$ & $25 / 28$ & $158 / 57$ & $325 / 119$ & $496 / 243$ & $763 / 552$ \\
\hline \multirow[t]{6}{*}{ Maize } & \multirow[t]{2}{*}{$\mathrm{LJ}$} & Upper & $3.0 \pm 1.3(\mathrm{a})$ & $4.8 \pm 2.0(\mathrm{a})$ & $3.3 \pm 1.3(\mathrm{a})$ & $4.9 \pm 0.9(a)$ & $7.6 \pm 3.0(\mathrm{a})$ & $7.4 \pm 2.5(\mathrm{a})$ & $6.7 \pm 2.6(\mathrm{a})$ & $8.5 \pm 1.5(\mathrm{a})$ & $4.9 \pm 1.1(\mathrm{a})$ \\
\hline & & Bottom & $1.6 \pm 1.1(\mathrm{a})$ & $1.7 \pm 0.5(\mathrm{a})$ & $1.7 \pm 1.8(\mathrm{a})$ & $1.9 \pm 1.0(\mathrm{a})$ & $3.6 \pm 0.7(a)$ & $4.5 \pm 0.3(\mathrm{a})$ & $2.8 \pm 0.8(\mathrm{a})$ & $3.7 \pm 1.2(\mathrm{a})$ & $6.9 \pm 1.5(\mathrm{~b})$ \\
\hline & \multirow[t]{2}{*}{ GF } & Upper & $2.4 \pm 0.4(\mathrm{a})$ & $3.6 \pm 1.0(\mathrm{a})$ & $4.4 \pm 1.5(\mathrm{a})$ & $3.9 \pm 1.3(\mathrm{a})$ & $3.3 \pm 1.4(\mathrm{a})$ & $4.6 \pm 2.0(a)$ & $5.2 \pm 1.2(\mathrm{a})$ & $3.0 \pm 0.7(\mathrm{a})$ & $4.6 \pm 1.4(\mathrm{a})$ \\
\hline & & Bottom & $3.0 \pm 0.9(\mathrm{a})$ & $2.7 \pm 0.6(\mathrm{a})$ & $2.1 \pm 0.5(\mathrm{a})$ & $3.0 \pm 0.6(\mathrm{a})$ & $1.9 \pm 0.2(\mathrm{a})$ & $1.3 \pm 0.5(\mathrm{a})$ & $1.6 \pm 1.0(\mathrm{a})$ & $1.5 \pm 0.8(\mathrm{a})$ & $2.1 \pm 1.1(\mathrm{a})$ \\
\hline & \multirow[t]{2}{*}{$\mathrm{D}$} & Upper & $3.3 \pm 1.4(\mathrm{a})$ & $2.1 \pm 1.1(\mathrm{a})$ & $2.4 \pm 1.6(a)$ & $2.1 \pm 0.1(\mathrm{a})$ & $3.4 \pm 2.2(\mathrm{a})$ & $1.8 \pm 1.0(\mathrm{a})$ & $3.6 \pm 1.1(a)$ & $1.4 \pm 0.5(\mathrm{a})$ & $1.5 \pm 0.8(\mathrm{a})$ \\
\hline & & Bottom & $0.2 \pm 0.1(\mathrm{a})$ & $2.1 \pm 1.7(b)$ & $1.3 \pm 0.2(\mathrm{ab})$ & $2.1 \pm 0.4(\mathrm{~b})$ & $0.5 \pm 0.4(\mathrm{a})$ & $1.0 \pm 0.2(\mathrm{a})$ & $1.4 \pm 1.4(\mathrm{a})$ & $1.5 \pm 0.2(\mathrm{a})$ & $1.1 \pm 0.7(a)$ \\
\hline \multirow[t]{6}{*}{ Wheat } & \multirow[t]{2}{*}{ LJ } & Upper & $2.7 \pm 0.5(\mathrm{ab})$ & $2.6 \pm 1.1(\mathrm{ab})$ & $1.9 \pm 0.4(\mathrm{a})$ & $4.0 \pm 1.4(b)$ & $2.8 \pm 1.5(\mathrm{a})$ & $4.4 \pm 0.7(\mathrm{ab})$ & $4.7 \pm 0.9(\mathrm{ab})$ & $3.4 \pm 0.7(\mathrm{ab})$ & $5.2 \pm 1.1(b)$ \\
\hline & & Bottom & $2.1 \pm 0.6(a)$ & $1.2 \pm 0.9(\mathrm{a})$ & $0.8 \pm 0.6(\mathrm{a})$ & $1.5 \pm 1.3(\mathrm{a})$ & $1.7 \pm 0.2(\mathrm{a})$ & $1.3 \pm 1.3(\mathrm{a})$ & $1.8 \pm 0.3(\mathrm{a})$ & $1.2 \pm 1.3(\mathrm{a})$ & $0.9 \pm 0.3(a)$ \\
\hline & \multirow[t]{2}{*}{ GF } & Upper & $8.5 \pm 1.2(\mathrm{a})$ & $6.6 \pm 0.8(a)$ & $9.5 \pm 2.2(\mathrm{a})$ & $24.7 \pm 3.3(\mathrm{~b})$ & $1.5 \pm 0.8(\mathrm{ab})$ & $2.0 \pm 0.7(\mathrm{ab})$ & $1.0 \pm 0.4(\mathrm{a})$ & $0.8 \pm 0.5(\mathrm{a})$ & $2.5 \pm 0.8(\mathrm{~b})$ \\
\hline & & Bottom & $2.7 \pm 0.7(\mathrm{a})$ & $2.1 \pm 0.7(\mathrm{a})$ & $2.3 \pm 1.0(\mathrm{a})$ & $2.2 \pm 0.7(a)$ & $1.1 \pm 0.5(\mathrm{a})$ & $0.8 \pm 0.5(a)$ & $1.4 \pm 0.3(\mathrm{a})$ & $1.1 \pm 0.3(\mathrm{a})$ & $0.8 \pm 0.5(\mathrm{a})$ \\
\hline & \multirow[t]{2}{*}{$\mathrm{D}$} & Upper & $0.9 \pm 0.6(a)$ & $3.0 \pm 1.5(\mathrm{a})$ & $3.3 \pm 0.3(\mathrm{a})$ & $14.8 \pm 2.4(\mathrm{~b})$ & $1.3 \pm 0.4(\mathrm{a})$ & $0.9 \pm 0.6(a)$ & $0.8 \pm 0.4(\mathrm{a})$ & $1.3 \pm 0.3(\mathrm{a})$ & $3.1 \pm 0.3(b)$ \\
\hline & & Bottom & $0.9 \pm 0.8(\mathrm{a})$ & $2.0 \pm 1.5(\mathrm{a})$ & $1.6 \pm 0.7(a)$ & $2.6 \pm 0.3(a)$ & $1.0 \pm 0.6(\mathrm{a})$ & $1.5 \pm 1.2(\mathrm{a})$ & $0.7 \pm 0.3(\mathrm{a})$ & $1.1 \pm 0.3(\mathrm{a})$ & $0.8 \pm 0.6(a)$ \\
\hline
\end{tabular}

\footnotetext{
${ }^{\text {a }}$ Soil $\mathrm{Hg}$ concentrations of $25,158,325,496$ and $763 \mathrm{ng} \mathrm{g}^{-1}$ were for maize, and the concentrations of $28,57,119,243$ and $552 \mathrm{ng} \mathrm{g}^{-1}$ for wheat. The same below.
} 

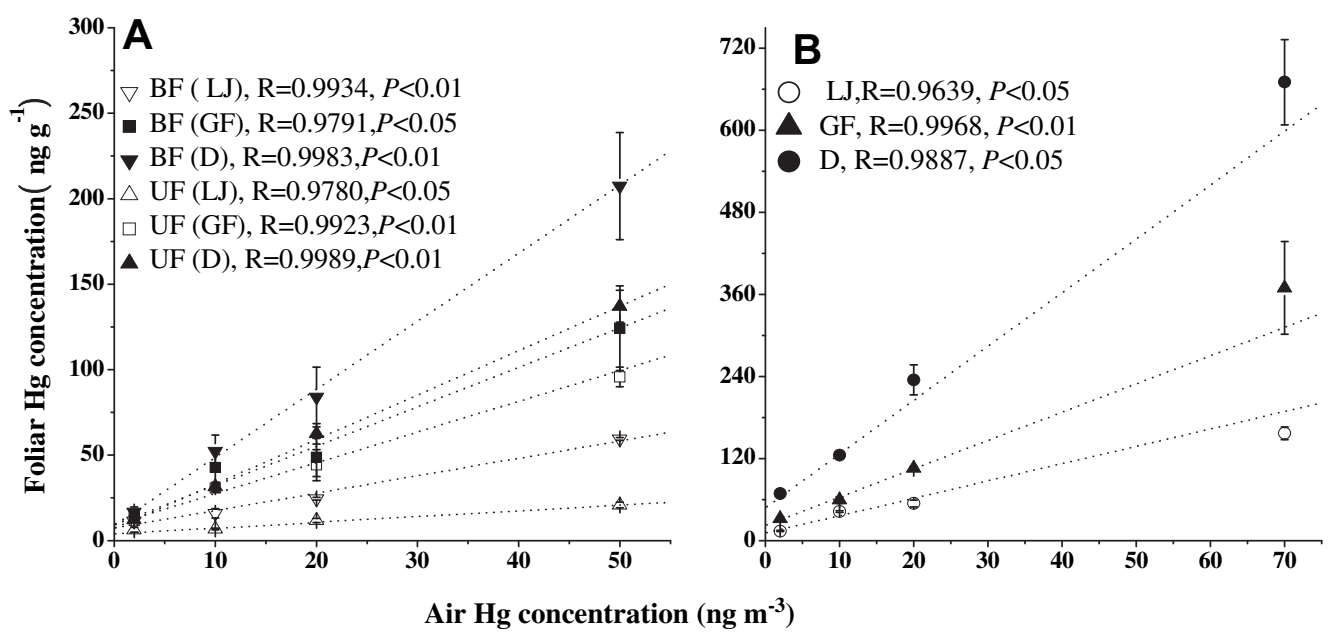

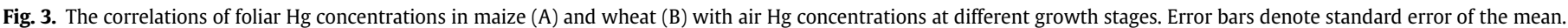
(Bottom Foliages (BF), Upper Foliages (UF)).

$70 \mathrm{ng} \mathrm{m}^{-3}$ at both GF and D stages $(p<0.05$ ) (Table 2), which suggested that elevated air $\mathrm{Hg}$ could enhance the $\mathrm{Hg}$ accumulation in wheat upper stems.

In soil $\mathrm{Hg}$ enriched experiment, except for the significant differences of maize bottom stems at $\mathrm{LJ}$ stage and wheat upper stems at both GF and D stages ( $p<0.05)$, most stem Hg concentrations in maize as well as wheat at all the stages were almost consistent under various soil $\mathrm{Hg}$ concentrations $(p>0.05)$. So, soil $\mathrm{Hg}$ generally had little influence on stem $\mathrm{Hg}$ accumulation (Table 2).

Under all treatments, the $\mathrm{Hg}$ concentrations in maize upper stems were usually higher than those in maize bottom stems, and the same results were found for wheat (Table 2). These results from the two experiments indicated that compared with soil $\mathrm{Hg}$, air $\mathrm{Hg}$ might have stronger influence on crop stem $\mathrm{Hg}$ accumulation, especially for upper stems.

\subsection{The correlation of $\mathrm{Hg}$ concentration between crop foliage and air}

Fig. 3 shows that foliar $\mathrm{Hg}$ concentrations in both maize and wheat had significant positive correlations with the air $\mathrm{Hg}$ concentrations at all the stages $(R=0.9639-0.9989, p<0.05)$. However, no such correlations were observed for soil Hg concentrations. These results suggested that the $\mathrm{Hg}$ accumulated in crop foliages was mainly from ambient air.

Although foliar $\mathrm{Hg}$ concentrations were not correlated significantly with the soil Hg concentrations ( $p>0.05$ ), the Hg concentrations in maize bottom foliages under different soil concentrations were obviously different at LJ stage $(p<0.05)$. The same results were found for maize upper foliages at GF stage $(p<0.05)$ and wheat foliages at both GF stage and D stage $(p<0.05)$ (Table 3$)$. These differences might result from the $\mathrm{Hg}$ translocation from roots to foliages, and the uptake by foliages from air $\mathrm{Hg}$ emitted from the $\mathrm{HgCl}_{2}$ enriched soil.

Under all treatments, the $\mathrm{Hg}$ concentrations in maize upper foliages were lower than those in bottom foliages at all the growth stages. Foliar $\mathrm{Hg}$ concentrations in maize and wheat increased over growth stages in both OTCs experiment (Fig. 3) and soil Hg enriched experiment (Table 3 ).

\subsection{The influence of air and soil $\mathrm{Hg}$ on seed $\mathrm{Hg}$ accumulation}

Seed $\mathrm{Hg}$ concentrations in maize and wheat were not significantly correlated with either air Hg concentrations $(p>0.05)$ or soil $\mathrm{Hg}$ concentrations $(p>0.05)$. Except for the highest seed $\mathrm{Hg}$ concentrations in wheat at $70 \mathrm{ng} \mathrm{m}^{-3}$ at GF and D stage $(p<0.05)$, no obvious differences of seed $\mathrm{Hg}$ concentrations in wheat were found in soil $\mathrm{Hg}$ enriched experiment $(p>0.05)$. The seed $\mathrm{Hg}$ concentrations in maize had slight variations under different air $\mathrm{Hg}$ concentrations treatments $(p>0.05)$, as well as soil Hg concentrations treatments $(p>0.05)$ (Table 4$)$. So air and soil Hg had little influence on crop seed $\mathrm{Hg}$ accumulation in these experiments.

\section{Discussion}

\subsection{The influence of $\mathrm{Hg}$ concentrations in air and soil on crop $\mathrm{Hg}$}

This study showed that the Hg concentrations in roots increased linearly with the increase of soil $\mathrm{Hg}$ concentrations at all the growth stages of the crops, while root $\mathrm{Hg}$ concentrations had no obvious

Table 3

Foliar $\mathrm{Hg}$ concentrations in maize and wheat at different growth stages in the soil Hg enriched experiment (ng $\left.\mathrm{g}^{-1}\right)$.

\begin{tabular}{|c|c|c|c|c|c|c|c|}
\hline Species & Stages & Foliages & $25 / 28$ & $158 / 57$ & $325 / 119$ & $496 / 243$ & $763 / 552$ \\
\hline \multirow[t]{6}{*}{ Maize } & $\mathrm{LJ}$ & Upper & $8.5 \pm 3.1(\mathrm{a})$ & $7.0 \pm 1.0(\mathrm{a})$ & $8.1 \pm 1.7(a)$ & $10.5 \pm 1.5(\mathrm{a})$ & $10.5 \pm 1.3(\mathrm{a})$ \\
\hline & & Bottom & $15.0 \pm 2.0(\mathrm{ab})$ & $16.0 \pm 2.0(a b c)$ & $14.3 \pm 4.5(\mathrm{a})$ & $21.0 \pm 3.5(\mathrm{c})$ & $20.3 \pm 1.5(b c)$ \\
\hline & GF & Upper & $14.0 \pm 1.0(a)$ & $14.0 \pm 1.0(\mathrm{a})$ & $12.3 \pm 1.2(\mathrm{a})$ & $14.0 \pm 3.0(a)$ & $15.7 \pm 0.6(b)$ \\
\hline & & Bottom & $14.3 \pm 4.0(\mathrm{a})$ & $15.0 \pm 7.0(a)$ & $15.7 \pm 1.2(\mathrm{a})$ & $22.7 \pm 5.0(a)$ & $19.3 \pm 3.1(a)$ \\
\hline & $\mathrm{D}$ & Upper & $15.0 \pm 1.7(a)$ & $16.0 \pm 1.0(a)$ & $15.3 \pm 1.5(\mathrm{a})$ & $17.3 \pm 1.5(\mathrm{a})$ & $16.7 \pm 0.6(a)$ \\
\hline & & Bottom & $24.0 \pm 1.7(a)$ & $20.7 \pm 3.1(a)$ & $21.0 \pm 3.0(a)$ & $24.3 \pm 2.5(a)$ & $20.7 \pm 1.5(\mathrm{a})$ \\
\hline \multirow[t]{3}{*}{ Wheat } & LJ & & $12.3 \pm 0.6(a)$ & $12.7 \pm 1.5(\mathrm{a})$ & $13.3 \pm 1.5(a)$ & $11.3 \pm 1.2(\mathrm{a})$ & $12.3 \pm 0.6(a)$ \\
\hline & GF & & $24.3 \pm 1.5(\mathrm{a})$ & $26.7 \pm 5.1(a)$ & $28.3 \pm 1.5(\mathrm{ab})$ & $32.7 \pm 0.6(\mathrm{bc})$ & $33.7 \pm 1.5(\mathrm{c})$ \\
\hline & $\mathrm{D}$ & & $44.7 \pm 3.1(a)$ & $50.0 \pm 3.1(a)$ & $47.3 \pm 2.9(a)$ & $59.3 \pm 4.2(\mathrm{~b})$ & $57.7 \pm 2.5(\mathrm{~b})$ \\
\hline
\end{tabular}


Table 4

Seed $\mathrm{Hg}$ concentrations in maize and wheat at different growth stages in the OTCs and soil Hg enriched experiments (ng $\mathrm{g}^{-1}$ ).

\begin{tabular}{|c|c|c|c|c|c|c|c|c|c|c|}
\hline \multirow[t]{2}{*}{ Species } & \multirow[t]{2}{*}{ Stages } & \multicolumn{4}{|c|}{ Air Hg concentrations $\left(\mathrm{ng} \mathrm{m}^{-3}\right)$} & \multicolumn{5}{|c|}{ Soil Hg concentrations ( $\mathrm{ng} \mathrm{g}^{-1}$ ) } \\
\hline & & 2 & 10 & 20 & $50 / 70$ & $25 / 28$ & $158 / 57$ & $325 / 119$ & $496 / 243$ & $763 / 552$ \\
\hline \multirow[t]{2}{*}{ Maize } & GF & $5.9 \pm 0.9(\mathrm{a})$ & $4.8 \pm 0.7(a)$ & $3.8 \pm 1.9(\mathrm{a})$ & $4.3 \pm 1.0(a)$ & $10.7 \pm 1.2(\mathrm{a})$ & $8.7 \pm 1.3(\mathrm{a})$ & $7.9 \pm 2.0(\mathrm{a})$ & $8.1 \pm 2.1$ (a) & $10.9 \pm 1.2(\mathrm{a})$ \\
\hline & $\mathrm{D}$ & $1.6 \pm 0.5(\mathrm{a})$ & $1.4 \pm 0.6(\mathrm{a})$ & $1.8 \pm 1.3(\mathrm{a})$ & $2.1 \pm 0.4(\mathrm{a})$ & $1.2 \pm 0.6(\mathrm{a})$ & $1.3 \pm 1.0(\mathrm{a})$ & $1.2 \pm 0.3(\mathrm{a})$ & $2.1 \pm 0.3(\mathrm{a})$ & $0.9 \pm 0.6(\mathrm{a})$ \\
\hline \multirow[t]{2}{*}{ Wheat } & GF & $0.8 \pm 0.2(\mathrm{a})$ & $0.6 \pm 0.4(\mathrm{a})$ & $0.7 \pm 0.3(\mathrm{a})$ & $1.6 \pm 0.5(b)$ & $0.9 \pm 0.8(\mathrm{a})$ & $0.5 \pm 0.4(\mathrm{a})$ & $0.1 \pm 0.1(\mathrm{a})$ & $0.7 \pm 0.5(\mathrm{a})$ & $0.7 \pm 0.4(\mathrm{a})$ \\
\hline & $\mathrm{D}$ & $0.7 \pm 0.0(\mathrm{a})$ & $1.1 \pm 0.3(\mathrm{a})$ & $0.6 \pm 0.1(\mathrm{a})$ & $2.7 \pm 1.0(\mathrm{~b})$ & $0.8 \pm 0.2(\mathrm{a})$ & $0.4 \pm 0.3(\mathrm{a})$ & $0.4 \pm 0.2(\mathrm{a})$ & $0.7 \pm 0.3(\mathrm{a})$ & $0.6 \pm 0.7(\mathrm{a})$ \\
\hline
\end{tabular}

linear relationships with air Hg concentrations, demonstrating that $\mathrm{Hg}$ accumulated in crop roots was mainly originated from soil. Many studies showed that the root $\mathrm{Hg}$ concentrations of trees were related to the soil $\mathrm{Hg}$ concentrations (e.g., Frescholtz et al., 2003; Ericksen et al., 2003; Millhollen et al., 2006a). Millhollen et al. (2006b) showed that higher soil Hg concentrations resulted in higher root $\mathrm{Hg}$ concentrations in grass and forb species. No evident influence of air $\mathrm{Hg}$ on root $\mathrm{Hg}$ accumulation in trees or crops was reported in previous studies. In this study, however, a significantly higher root $\mathrm{Hg}$ concentration in wheat exposed to $70 \mathrm{ng} \mathrm{m}^{-3}$ was observed at D stage $(p<0.05)$ of the growth, which might result from the translocation of $\mathrm{Hg}$ from foliages to roots, accompanied by the translocation of photosynthate, but further research is needed to confirm this process. In addition, no statistical difference $(p>0.05)$ of $\mathrm{Hg}$ concentrations for surface soils $(3-5 \mathrm{~mm})$ in chambers were found before ( $\left.27 \pm 7 \mathrm{ng} \mathrm{g}^{-1}\right)$ and after $\left(27 \pm 4 \mathrm{ng} \mathrm{g}^{-1}\right)$ the fumigation. The GEM fumigation did not change the soil $\mathrm{Hg}$ concentrations in chambers, therefore, the significant difference of the root $\mathrm{Hg}$ concentration in wheat at D stage may be influenced by air $\mathrm{Hg}$ concentration.

Accumulation of $\mathrm{Hg}$ in plant stems may result from a combination of atmospheric uptake and translocation from root uptake. In the two experiments, the air $\mathrm{Hg}$ concentration $\left(70 \mathrm{ng} \mathrm{m}^{-3}\right)$ led to a significant increase of $\mathrm{Hg}$ accumulation in wheat upper stems $(p<0.05)$, while soil $\mathrm{Hg}$ generally had little influence on $\mathrm{Hg}$ accumulation in crop stems. In addition, $\mathrm{Hg}$ concentrations in upper stems were usually higher than those in bottom stems. These results suggested that the air $\mathrm{Hg}$ played a more important role than soil $\mathrm{Hg}$ in the $\mathrm{Hg}$ accumulation in crop stems, which was in accordance with the results for trees. Fay and Gustin (2007) showed that trunk $\mathrm{Hg}$ concentrations in trees and shrub were influenced by both air and soil $\mathrm{Hg}$ concentrations, and the influence of air $\mathrm{Hg}$ was stronger.

In this study, significant positive correlations were found between foliar $\mathrm{Hg}$ concentrations and air $\mathrm{Hg}$ concentrations, while foliar $\mathrm{Hg}$ concentrations did not show obvious linear relationships with soil $\mathrm{Hg}$ concentrations, which indicates that $\mathrm{Hg}$ in crop foliages was mainly taken up from ambient air. These results were consistent with those from previous studies for tree foliages (e.g., Frescholtz et al., 2003; Ericksen et al., 2003; Ericksen and Gustin, 2004; Millhollen et al., 2006a). De Temmerman et al. (2007, 2009) also showed linear correlations $\left(R^{2}=0.64-0.98\right)$ between foliar $\mathrm{Hg}$ concentrations and air $\mathrm{Hg}$ concentrations in ryegrass and leafy vegetables. Elevated soil $\mathrm{Hg}$ concentrations had some influence on the foliar $\mathrm{Hg}$ concentrations at some stages $(p<0.05)$, which may be due to the emission from $\mathrm{Hg}$ enriched soil and translocation to the foliages from roots. Millhollen et al. (2006b) showed that the high $\mathrm{Hg}$ concentrations in leaves in blackeyed susan (Rudbeckia hirta L.) were caused by the $\mathrm{Hg}$ emission from soil, because the bottom leaves of $R$. hirta were very close to the ground. Foliar Hg concentrations in crop showed the trend of increase over growth stages in this study, and many other studies also reported that foliar $\mathrm{Hg}$ concentrations in trees and shrub increased as a function of plant growth stages (Ericksen et al., 2003; Frescholtz et al., 2003; Millhollen et al., 2006a; Fay and Gustin, 2007).

At the treatment of $\mathrm{CK}$, the $\mathrm{Hg}$ concentrations in crop organs increased in the order of seeds $<$ stems $<$ roots $<$ foliages in the two experiments. Ericksen et al. (2003) reported that the Hg concentrations in tree organs increased in the order of stems $<$ branches $<$ roots $<$ leaves. So, the $\mathrm{Hg}$ accumulation from air in crop organs was mainly retained in foliages.

\subsection{Health implication of crop production with elevated $\mathrm{Hg}$ exposure}

In this study, the seed $\mathrm{Hg}$ concentrations at GF and D stages were lower than the Chinese tolerance limit of $\mathrm{Hg}$ for food $\left(20 \mathrm{ng} \mathrm{g}^{-1}\right)$ (CNSA, 1994). However, the foliar Hg concentrations in crop in this study exceed the European Commission (2002) $\mathrm{Hg}$ standard for livestock (110 $\mathrm{ng} \mathrm{g}^{-1}$, dry weight) at high air $\mathrm{Hg}$ exposure and also exceed the Kazakhstan (Ullrich et al., 2007) standard for livestock $\left(100 \mathrm{ng} \mathrm{g}^{-1}\right)$. Therefore, from the OTCs experiment, it can be concluded that crop foliages grown in the area with elevated air $\mathrm{Hg}$ concentration ( $50 \mathrm{ng} \mathrm{m}^{-3}$ or higher) may be not suitable for fodders.

\section{Acknowledgments}

We thank Yujing Mu, Wenzhi Song, Yi Zhang, Sen Wang, Zhanyi Wang and Ming Zeng from the Research Center for EcoEnvironmental Sciences, Chinese Academy of Sciences, for their suggestions and help in the field study. We also thank Xiangrui Kong from University of Gothenburg, Sweden, Rixiang Huang from Baylor University, American, and Jiaowei Tang from Copenhagen University, Denmark, for the help in English editing of this paper. This work was funded by the National Natural Science Foundation of China (No. 40803033 and 41073092). The anonymous reviewers are acknowledged for their valuable comments.

\section{References}

Bao, S.D., 2000. Soil and Agricultural Chemistry Analysis. China Agricultural Press, pp. 84, 109, 131.

Barghigiani, C., Ristori, T., Bauleo, R., 1991. Pinus as an atmospheric Hg biomonitor Environmental Technology 12, 1175-1181.

Bishop, K.H., Lee, Y.H., Munthe, J., Dambrine, E., 1998. Xylem sap as a pathway for total mercury and methylmercury transport from soils to tree canopy in the boreal forest. Biogeochemistry 40, 101-113.

Chen, B., Wang, X.R., Lee, F.S.C., 2001. Pyrolysis coupled with atomic absorption spectrometry for the determination of mercury in Chinese medicinal materials. Analytica Chimica Acta 447, 161-169.

Chinese National Standard Agency (CNSA), 1994. Tolerance Limit of Mercury in Foods, GB 2762-1994; Beijing, pp. 171-173.

De Temmerman, L., Claeys, N., Roekens, E. Guns, M., 2007. Biomonitoring of airborne mercury with perennial ryegrass cultures. Environmental Pollution 146, 458-462.

De Temmerman, L., Waegeneers, N., Claeys, N., Roekens, E., 2009. Comparison of concentrations of mercury in ambient air to its accumulation by leafy vegetables: an important step in terrestrial food chain analysis. Environmenta Pollution 157, 1337-1341. 
Dunagan, S.C., Gilmore, M.S., Varekamp, J.C., 2007. Effects of mercury on visible/ near-infrared reflectance spectra of mustard spinach plants (Brassica rapa $\mathrm{P}$.) Environmental Pollution 148, 301-311.

Engle, M.A., Gustin, M.S., Zhang, H., 2001. Quantifying natural source mercury emissions from the Ivanhoe Mining District, north-central Nevada, USA. Atmospheric Environment 35, 3987-3997.

Ericksen, J.A., Gustin, M.S., 2004. Foliar exchange of mercury as a function of soil and air mercury concentrations. Science of the Total Environment 324 , 271-279.

Ericksen, J.A., Gustin, M.S., Schorran, D.E., Johnson, D.W., Lindberg, S.E. Coleman, J.S., 2003. Accumulation of atmospheric mercury in forest foliage. Atmospheric Environment 37, 1613-1622.

Ericksen, J.A., Gustin, M.S., Lindberg, S.E., Olund, S.D., Krabbenhoft, D.P., 2005 Assessing the potential for re-emission of mercury deposited in precipitation from arid soils using a stable isotope. Environmental Science and Technology 39, 8001-8007.

European Commission, 2002. Amended proposal for a Directive of the European Parliament and of the Council on undesirable substance and products in animal nutrition. Official Journal, 346-361. C 096 E, 27/03/2001.

Fay, L., Gustin, M., 2007. Assessing the influence of different atmospheric and soil mercury concentrations on foliar mercury concentrations in a controlled environment. Water, Air, and Soil Pollution 181, 373-384.

Fitzgerald, W.F., Mason, R.P., Vandal, G.M., 1991. Atmospheric cycling and air-water exchange of mercury over mid-continental lacustrine regions. Water, Air, and Soil Pollution 56, 745-767.

Food and Agriculture Organiztion (FAO), 2009. Statistical Yearbook 2009 of Land Use. http://www.fao.org/fileadmin/templates/ess/documents/publications studies/statistical_yearbook/yearbook2009/a04.xls.

Frescholtz, T.F., Gustin, M.S., Schorran, D.E., Fernandez, G.C.J., 2003. Assessing the source of mercury in foliar tissue of quaking aspen. Environmental Toxicology and Chemistry 22, 2114-2119.

Friedli, H.R., Arellano, A.F., Cinnirella, S., Pirrone, N., 2009. Initial estimates of mercury emission to the atmosphere from global biomass burning. Environmental Science and Technology 43, 3507-3513.

Greger, M., Wang, Y.D., Neuschütz, C., 2005. Absence of Hg transpiration by shoot after $\mathrm{Hg}$ uptake by roots of six terrestrial plant species. Environmental Pollution 134, 201-208.

Gustin, M.S., Lindberg, S.E., Austin, K., Coolbaugh, M., Vette, A., Zhang, H., 2000. Assessing the contribution of natural sources to regional atmospheric mercury budgets. Science of the Total Environment 259, 61-71.

Gustin, M.S., Lindberg, S.E., Weisberg, P.J., 2008. An update on the natural sources and sinks of atmospheric mercury. Applied Geochemistry 23, 482-493.

Heagle, A.S., Body, D.E., Heck, W.W., 1973. An open-top field chamber to assess the impact of air pollution on plants. Journal of Environmental Quality 2, 365-368.
Lindberg, S.E., Porcella, D., Prestbo, E., Friedli, H., Radke, L., 2004. The problem with mercury: too many sources, not enough sinks. RMZ-Materials and Geoenvironment 52, 1172-1176.

Lindberg, S.E., 1996. Forests and the global biogeochemical cycle of mercury: the importance of understanding air/vegetation exchange processes. In: Baeyens, W. (Ed.), Regional and Global Mercury Cycles. NATO Advanced Science Institute Series, Novosibersk, Siberia. Kluwer Academic Publisher, Dordrecht, Holland, pp. 359-380.

Lindqvist, O., Rodhe, H., 1985. Atmospheric mercury-a review. Tellus B 37, 136-159.

Millhollen, A.G., Gustin, M.S., Obrist, D., 2006a. Foliar mercury accumulation and exchange for three tree species. Environmental Science and Technology 40, 6001-6006.

Millhollen, A.G., Obrist, D., Gustin, M.S., 2006b. Mercury accumulation in grass and forb species as a function of atmospheric carbon dioxide concentrations and mercury exposures in air and soil. Chemosphere 65, 889-897.

Obrist, D., 2007. Atmospheric mercury pollution due to losses of terrestrial carbon pools? Biogeochemistry 85, 119-123.

Pirroni, N., Costa, P., Pacyna, J.M., Ferrara, R., 2001. Mercury emissions to the atmosphere from natural and anthropogenic sources in the Mediterranean region. Atmospheric Environment 35, 2997-3006.

Rea, A.W., Lindberg, S.E., Scherbatskoy, T., Keeler, G.J., 2002. Mercury accumulation in foliage over time in two northern mixed-hardwood forests. Water, Air, and Soil Pollution 133, 49-67.

Schwesig, D., Krebs, O., 2003. The role of ground vegetation in the uptake of mercury and methylmercury in a forest ecosystem. Plant and Soil 253, 445-455.

Shuvaeva, O.V., Gustaytis, M.A., Anoshin, G.N., 2008. Mercury speciation in environmental solid samples using thermal release technique with atomic absorption detection. Analytica Chimica Acta 621, 148-154.

St. Louis, V.L., Rudd, J.W.M., Kelly, C.A., Hall, B.D., Rolfus, K.R., Scott, K.J., Lindberg, S.E., Dong, W., 2001. Importance of the forest canopy to fluxes of methyl mercury and total mercury to boreal ecosystems. Environmental Science and Technology 35, 3089-3098.

Stamenkovic, J., Gustin, M.S., 2009. Nonstomatal versus stomatal uptake of atmospheric mercury. Environmental Science and Technology 43, 1367-1372.

Ullrich, S.M., Ilyushchenko, M.A., Tanton, T.W., Uskov, G.A., 2007. Mercury contamination in the vicinity of a derelict chlor-alkali plant: part II: contamination of the aquatic and terrestrial food chain and potential risks to the local population. Science of the Total Environment 381, 290-306.

Veiga, M.M., Meech, J.A., Oñate, N., 1994. Mercury pollution from deforestation. Nature 368, 816-817.

Wang, Z.W. Zhang, X.S., Xiao, J.S., Ci, ZJ., Yu, P.Z, 2009. Mercury fluxes and pools in three subtropical forested catchments, southwest China. Environmental Pollution 157, 801-808

Zhu, X.C., Qing, C.L., Pi, G.J., 1996. Study on soil mercury fractions and their influencing factors. Acta Pedologica Sinica 33, 94-100. 